\title{
Simultaneous adoption of integrated soil fertility management technologies in the Chinyanja Triangle, Southern Africa
}

\author{
Powell Mponela $\odot$, Girma T. Kassie and Lulseged D. Tamene
}

\begin{abstract}
Empirical scientific evidence indicates that there is still room for increasing food production by improving land productivity. This study aimed at identifying the key determinants that govern farmers' decisions to adopt multiple components of integrated soil fertility management (ISFM) in a maize mixed cropping system of the Chinyanja Triangle, Southern Africa. Revealed preferences of ISFM components were collected from 320 randomly selected households and multivariate probit (MVP) model was used to analyse the simultaneous effects on adoption based on biophysical plot and household-level socioeconomic attributes. The results show that farmers' choices of a set of ISFM components are determined by a mix of factors that address the trade-offs and synergies among them. Non-farm income, moderate land quality perception, and education influence simultaneous technology adoption, while gender and crop loss increase the likelihood of farmers' decisions to adopt independent options. Having other sources of income supports co-adoption of inorganic fertilizer, residue incorporation, and crop rotation. Input/output market access, access to information, financial sources, and climate variability also play pivotal role in technology adoption. These results indicate that resource availability, learning costs, finances, and risk aversion need to be considered when designing and promoting ISFM technologies as a package.
\end{abstract}

Keywords: Integrated soil fertility management; simultaneous adoption; resource scarcity; learning; risk aversion; Chinyanja Triangle.

\section{Introduction}

Why do small-scale farmers in southern Africa selectively use different components of integrated soil fertility management (ISFM) on their farms? Which ISFM components do farmers usually practise together? What are the main controlling factors that facilitate the combined ISFM component (dis)adoption? These are among the most common questions that researchers and extension agents in southern Africa try to have prior answers to as they advance the technologies tested on small plots to the wider community (Maat, 2011; Kravchenko et al., 2017). To date, several technologies have been developed through scientific experiments and rolled out to farms through on-farm demonstrations. Efforts to address challenges of declining soil fertility using integrated approaches started in the 1990s

Powell Mponela is at the Rheinische Friedrich-Wilhelms-Universität Bonn, Center for Development Research (ZEF), Bonn, Germany. E-mail: s7pompon@uni-bonn.de

Girma T. Kassie is at the International Center for Agricultural Research in the Dry Areas (ICARDA), ILRI Campus, Addis Ababa, Ethiopia. E-mail: g.tesfahun@cgiar.org

Lulseged D. Tamene is at the International Center for Tropical Agriculture (CIAT), C/O IRLI, Addis Ababa, Ethiopia. E-mail: LT.Desta@cgiar.org
(Mugwe et al., 2009; Sanginga and Woomer, 2009). Since then, researchers have been suggesting modifications to the packaging of the components, but the technologies themselves are not new to practitioners (Coe et al., 2016). Apparently, farmers have been using the components such as animal manure, trees on farm, intercropping, and rotation for decades. They iteratively select technologies that have been shown to have higher benefits and drop the technologies that have higher negative risks in tandem with suitability to their soils, micro-climate, and other biotic and abiotic conditions. Often the drivers of their choices are in contrast to the potential technological gains reported on research trials (Marenya and Barrett, 2007; Wiredu et al., 2014; Coe et al., 2016).

The need to improve land productivity through implementing ISFM at the farm/plot level is gaining increased research attention (Thirtle et al., 2003; Jama and Pizarro, 2008; Tilman et al., 2011). The agronomic studies have shown that there is still room (high yield gaps) for increasing food production and meet the need to feed the growing population, but the local conditions are limiting (Mueller et al., 2012; Tittonell and Giller, 2013; Snyder et al., 2016; Tamene et al., 2016). The ISFM components, used in different combinations, are potentially suited to address these 
multiple constraints (Vanlauwe et al., 2010; Giller et al., 2011). It is projected that by the year 2050, ISFM technologies could increase maize yields in the Sub-Saharan Africa (SSA) region by 21.5\% (Rosegrant et al., 2014). From an economic standpoint, studies have also revealed that the cost of implementing ISFM technologies is lower than the opportunity costs associated with not investing resources in soil fertility management (Nkonya et al., 2016). In their study, based on data from seven countries in Sub-Saharan Africa, Nkonya et al. (2016) found that farmers who integrate inorganic and organic soil fertility management technologies get higher profits in the range of $50 \%$ compared to sole fertiliser users, $600 \%$ over sole manure users, and $2,000 \%$ more than farmers currently not applying any soil fertility measure. The key concern is that the number of those not practising is higher, ranging between $27-95 \%$ of farm households, while those practising integrated technologies are much lower (0-18\%) (Nkonya et al., 2016).

The initial step to unlock the potential of technologies and facilitate their diffusion is to understand the constraints and reinforcing factors (Rodgers, 2003). The complexity of the ISFM components in the form of: (a) multiple interacting inputs and processes; (b) temporal variability; (c) multiple economic contributions; and (d) off-farm impacts poses analytical challenges. The ISFM framework proposed in 2010 (Vanlauwe et al., 2010) calls for stepwise knowledge paradigm shifts from the current farmer practice of low levels of usage of improved varieties and inorganic fertilizers to the full-fledged ISFM package that includes complementary organic matter sources and good husbandry practises. Recent studies in the region have shown that most of the farmers are stagnating at the lower end of the ISFM ladder, and slowly adopting improved germplasm and inorganic fertilisers (Jha and Hojjati, 1993; Denning et al., 2009; Mponela et al., 2016). The incorporation of locally available organic resources and the adaptation of globally/regionally proven technologies to local socioeconomic and biophysical conditions have faced low adoption rates (Nkonya et al., 2016).

Often, farmers routinely acquire information about technologies and simultaneously use ISFM components on the same plot as a package (Vanlauwe et al., 2010; Mponela et al., 2016). Therefore, the observed usage captured through one-off surveys is a result of simultaneous and inter-dependent past decisions (Kassie et al., 2015). To capture the true nature of the decision processes, all possible combinations of components need to be considered in the decision set. Within the smallholder farming systems, the combinations of ISFM components available to the farmer tend to be large (Mponela et al., 2016), making it more difficult for them to decide and for the researchers to interpret the effects of explanatory variables on each of the components and their combinations. Adoption or technology use is defined as the outcome of optimising utility by heterogeneous agents (Rodgers, 2003; Ajayi et al., 2007;
Foster and Rosenzweig, 2010). If each bundle is thought of as a possible decision set by the farmer, then the farmer is expected to choose the bundle that maximises his expected utility. Thus, given that a rational household evaluating the difference $\left(\Delta_{i}\right)$ in utility from adoption $U_{A i}$ and nonadoption $U_{N i}$ of ISFM measures, it will choose to adopt, if the utility gained from adopting is greater than the utility of not adopting $\left(\Delta_{i}=U_{A i}-U_{N i}>0\right)$. Tacitly, utilities include profit, cost, and risk impacts of the adoption decisions.

The aim of the study is to explore factors that influence multiple adoption of ISFM components in maize mixed cropping systems of the Chinyanja Triangle. In doing so the study will: (i) identify complementarities among ISFM components used by smallholder farmers; and (ii) determine key farm and household attributes that drive farmers' decisions to simultaneously adopt multiple ISFM components. As discussed in the preceding paragraphs, the immediate difficulties in analysing adoption of ISFM technologies are the potential simultaneity of the adoption decision. Accordingly, this study uses a multivariate probit (MVP) model to analyse simultaneous and interdependent decisions by farm households in adopting ISFM components (Kassie et al., 2015). It is postulated that understanding the adoption decision-making process for technologies with interdependent components being used by heterogeneous farming households would contribute to better development and dissemination of ISFM technologies.

The remaining sections of the paper are structured as follows. In section 2, we discuss the methodology employed in the study detailing conceptualisation of the adoption of ISFM, the data generation process, and econometric modelling. In sections 3 and 4, the results are presented and discussed. Section 5 finalizes the paper with concluding remarks that pertain to the key results of the study.

\section{Methodology}

\subsection{Study area}

The study was conducted in the Dedza and Ntcheu districts of Central Malawi, Macanga district of Mozambique, and Mambwe district of Eastern Zambia (Figure 1). The people of the area, apart from sharing a language (i.e., Chinyanja), have similar beliefs and norms regarding land acquisition and management (Amede et al., 2014). The natural vegetation dominated by miombo woodlands in the region has also shaped the communities' natural resource utilisation since most of the inhabitants continue to rely on wild collections of timber and non-timber woodland products. Until recently, when Malawi enacted new land laws, the land tenure regulations did not differ in the three study countries. Though the land is officially owned by the government, the traditional leaders oversee the transfer among 


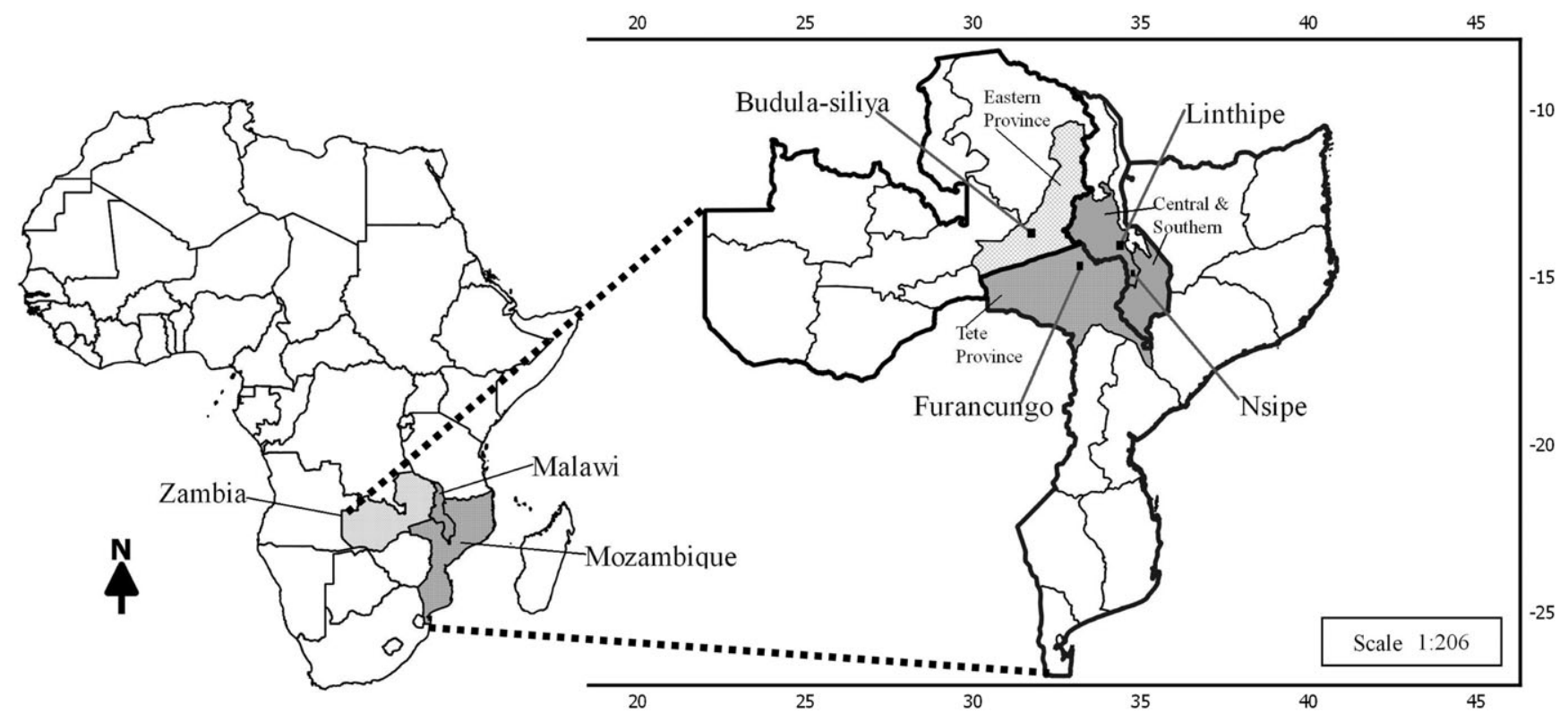

Figure 1. Survey locations within the Chinyanja Triangle covering the Eastern Province of Zambia, the central and southern regions of Malawi, and the Tete Province of Mozambique. Note: The coordinates are in degrees.

family members. For the Nyanja, the inheritance is through a matrilineal lineage system (CGIAR, 2014). Although the three countries have robust environmental legal frameworks, lack of incentives coupled with insecurity of customary land tenure, weaknesses in enforcement and social safeguards, and low public awareness have led to unregulated use of land (Dalupan et al., 2015; Sambo et al., 2015). This caused the emergence of mosaic land use patterns where individual farmers adjust the technologies to own limitations (Coe et al., 2016; Sileshi and Akinnifesi, 2017).

The Chinyanja Triangle has three distinct ecological zones with plateaus on the northern end, sub-humid escarpments around the centre, and semi-arid Shire, Luangwa, and Zambezi river valleys towards the south. The study was conducted in the sub-humid escarpments that face higher demand for cropland (Denning et al., 2009). The sites fall within the maize mixed farming system (Dixon et al., 2001), extending across plateau and highland areas at altitudes of 800 to 1,500 m, from Kenya and Tanzania to Zambia, Malawi, Zimbabwe, South Africa, Swaziland, and Lesotho.

Maize is the main staple food while cash sources are migrant remittances, cattle, small ruminants, tobacco, and cotton, as well as sale of maize and pulses (Njuki et al., 2008). Nsipe in Ntcheu District and Linthipe in Dedza district - both in Malawi - have been under cultivation for several generations (Mponela et al., 2016). The Furancungo site in the Macanga district of Mozambique and Budula-siliya in the Mambwe district of Zambia were acquired through resettlement and agricultural expansion programmes, and have been cultivated by up to three generations (Smart and Hanlon, 2014; Mponela et al., 2016).
Population densities (people $\mathrm{km}^{-2}$ ) are lower in Macanga and Mambwe with nine and 13, but relatively higher in Ntcheu and Dedza districts with 108 and 172, respectively (Republica de Mocambique, 2005; Republic of Malawi, 2008; Republic of Zambia, 2010). Land holdings also vary from 0.5 ha in the south of Malawi to 2.0 ha in Zambia and Mozambique (Amede et al., 2014).

\subsection{Sampling frame and sample size}

The study was conducted in areas covered by the CGIAR Research Programme on Dryland Systems and Africa RISING projects, and implemented by the International Centre for Tropical Agriculture (CIAT). Households were sampled using multistage spatially stratified random sampling following the framework developed for land degradation surveillance (LDSF) designed to assess landscape conditions and soil health (Vågen et al., 2015). The sampling framework was designed such that sentinel site covers an area of $10 \mathrm{~km}^{2}$ within which 16 clusters are formed. Each cluster covers an area of $2.5 \times 2.5 \mathrm{~km}^{2}$, with 10 randomly located sampling plots of 0.1 ha. A household survey was conducted with households that own and manage the sampled LDSF plots. Five households were randomly drawn from the list of owners/users of the 10 plots, thereby geo-referencing farmers to the sampled plots. Three hundred and twenty households from the four sites were surveyed. The data were collected between December 2012 and June 2013, and included ISFM technology use, socio-demographic, and economic characteristics of the households, land characteristics, and resources endowments. 


\subsection{Empirical model}

Through a review of available literature on agricultural technology adoption, Lambrecht et al. (2016) discuss the practical patterns of interrelated technology adoption, which can be differentiated into: independent, sequential, or simultaneous. For the independent decisions, the probability of applying one technology is not affected by adoption of another technology. Using this assumption, several studies focused on the adoption of individual ISFM technologies (Bationo et al., 2007; Mugwe et al., 2009; Sanginga and Woomer, 2009). The studies that treat adoption as a binary choice of individual ISFM provide useful starting points for selecting variables of importance (Akinola et al., 2010; Wiredu et al., 2014; Kassie et al., 2015). However, they do not explore the simultaneous and interdependent adoption behaviour (Kassie et al., 2015).

Under the ISFM framework, the decision to adopt one component is related to the same decision regarding other components (Tsegaye et al., 2016). The probability of practicing a technology within a component subset is conditioned by a preceding (consequential) or joint (simultaneous) application of a technology from another component. Lambrecht et al. (2016) further notes that besides the technical aspects, socioeconomic factors such as awareness, availability, input requirements, risk, and local practices could affect the adoption patterns. Accounting for these unobserved factors and inter-relationships among adoption decisions regarding different components reduces bias and improves the estimate (Belderbos et al., 2004). Consequently, the multivariate limited dependent variable (multivariate probit) model is used to analyse the interrelated decisions of adopting each of the components of IFSM (Tsegaye et al., 2016). The multivariate probit model simultaneously accounts for the influences of the set of explanatory variables on each of the different practices while allowing the unobserved and unmeasured factors (error terms) to be freely correlated (Belderbos et al., 2004).

A typical farm household would be adopting one or more of the components of ISFM if and only if the expected benefit is higher than otherwise. Although the ISFM components are framed on the assumption that synergistic results can be obtained when complementary technologies are co-implemented (Nkonya et al., 2016), there is also an array of similar technologies within the subset of components that can be substituted (Lambrecht et al., 2016). The equation for multivariate probit model is structured following Kassie et al. (2015) and Tsegaye et al. (2016) as:

$$
\begin{aligned}
& Y_{i m}=\beta_{m} X_{i m}+\varepsilon_{i m}, m=1 \ldots M, \text { with } \\
& Y_{i m}^{*}=1 \text { if } Y_{i m}>0 \text { and } 0 \text { otherwise. }
\end{aligned}
$$

The $Y_{i m}$ is a latent variable that denotes the perceived utility of individual " $P$ " in adopting " $m$ " component(s) of IFSM. This latent variable is assumed to be a linear combination a vector of observed characteristics $X_{\mathrm{i}}$ with $\beta_{m}$ estimable parameters, as well as unobserved characteristics captured by the error term $\varepsilon_{i m}$.

Given the latent nature of $Y_{i m}^{*}$, the estimations are based on observable binary discrete variable $Y$, which indicates whether or not a farmer applied/adopted a particular ISFM technology. In other words, $Y_{i m}^{*}$ represents the outcome for $\mathrm{M}$ different components during the survey period. If the adoption of a particular practice is independent of whether or not a farmer adopts another practice (i.e., if the error terms, $\epsilon_{i m}$ follow a standard normal distribution), then Equation (1) would reduce to a binary probit model. In this case, information on farmers' adoption of one ISFM component does not alter the prediction of the probability that they will adopt another component (Lambrecht et al., 2016). However, if farmers adopt several ISFM components, it is more likely that the adoption of one component would affect the probability of adopting another (Lambrecht et al., 2016), and the error terms in Equation (1) jointly follow a multivariate normal (MVN) distribution, with zero conditional mean and variance matrix $\left(\sum\right)$ normalized to unity, where $\epsilon_{\text {im }} \sim \operatorname{MVN}\left(0, \sum\right)$, hence the need for using multivariate probit model.

We adapted the Stata procedure, mvprobit, by Cappellari and Jenkins (2003), which uses the simulated maximum likelihood (SML) and allows for an extended number of draws. For an M-variate case, there are M! (factorial) possible combinations of adoption $\left(Y_{i m}^{*}=1\right)$ and non-adoption $\left(Y_{i m}^{*}=0\right)$. If farmers adopt all the components, the probability that every outcome is a success is a conditional combination of the probabilities of every component as influenced by explanatory variables. The joint probabilities for each of the other outcome combinations (adoption of only a few and non-adoption) are conditional probabilities of both successes and failures. The SML is the recursive conditional evaluation of these joint probabilities, which are unbiased, bounded within the $[0,1]$ interval, and generated through continuous differentiation of the model.

\subsection{The dependent variables}

Among the components of ISFM as depicted in the framework by Vanlauwe et al. (2010), the main soil fertility amendments implemented in the study areas were considered for this paper. In the region, the adoption of ISFM components varies greatly, with inorganic fertiliser being the most widely applied. The higher adoption of fertilisers is supported by the government's farm input subsidy programme coupled with the immediate returns observed, especially when applied to improved varieties than when applied to local varieties (Benson, 1997; Holden, 2015). Some farmers do not use inorganic fertilisers, and instead they use some of the organic technologies, while a proportion of the farmers solely use fertiliser. Apart from the traditionally rooted system of rotating crops of different 
nutrient requirements and pest and disease, the incorporation of organic sources is still at lower levels. Despite the importance of grain legumes as sources of protein and income, some farmers may not recognise their roles, and grow them partly for soil fertility amelioration.

Usage of compost manure is still low despite nutrient analysis of compost manure produced by smallholder farmers in Malawi, showing that it contains considerable amounts of nutrients to boost production (Chilimba et al., 2005). A larger proportion of farmers, especially those in the newly opened areas in Budula-siliya, put their land to natural fallow. Lime and mulch are the least used in the four sites. Several other studies show that farmers apply only a subset of technologies, even if applying the whole package would be more profitable (Lambrecht et al., 2016).

\subsection{The explanatory variables}

Since the unit of analysis is the farm household, the dependent variables considered are those that have been found in previous research to drive household-level decisions. When making agricultural management decisions, farmers are constrained by four main factors: resource scarcity, financial constraint, learning cost, and risk aversion (Foltz, 2003; Marenya and Barrett, 2007). Such constraints for different technologies can interact, leading to a socioeconomic rationale for inter-relationships in the application of different technologies. Meta-analyses and literature reviews of agricultural, forestry, and land management technologies have grouped factors influencing the adoption of technologies using socioeconomic and ecological hypotheses structured into five categories, namely, farmer preferences, resource endowments, market incentives and policies, biophysical and technological factors, and learning cost and risk aversion (Feder, 1985; Pattanayak et al., 2002; Lambrecht et al., 2016). Preferences define the objectives and motivations of the economic agents choosing technologies, while resource endowments enable their technology choices. Market incentives and biophysical factors condition the extent, timing, and nature of the technology choices, while risk and uncertainty govern farmers' expectations in favour of investments that pay dividends only in the short run.

Farmer preferences are not captured numerically and depend on state of mind; hence socio-demographic proxies including age, education, and social status are used instead. Studies have found differing influences of these attributes; therefore, it is not possible to, a priori, set the direction of effect (Feder, 1985; Doss, 2006). Resource endowments measure the resources available to the technology adopter for implementing the new technology. Generally, resource endowments are likely to be positively correlated with the probability of adoption (Marenya and Barrett, 2007; Langyintuo and Mungoma, 2008; Mugwe et al., 2009; Bezu et al., 2014). However, the counter-hypothesis states that increasing resource scarcity (such as depletion of soil fertility) leads to higher shadow prices, causing some farmers to try combined use of resource-saving technologies (Foltz, 2003). Farmers with fertile soils thus may not adopt. Resource endowment reflects household assets including possession of land, livestock, and household items. To derive a single unit, the different livestock species in this study were converted into standard livestock units (LU) using nutritional and feed requirement factors for Africa (Jahnke, 1982; Chilonda and Otte, 2006).

Biophysical factors relate to influences on the physical production process associated with farming. In general, poorer biophysical production conditions, such as declining soil fertility of small land holdings, create a positive incentive to adopt technologies that will alleviate these situations (Ajayi et al., 2007). However, it is also possible that some farms are of a size that is below the threshold of useful investment, and thus technology investment may not be a worthwhile intervention (Guastella et al., 2013). Lower learning costs such as for farmers with access to information about the technology through better education, own experience from years of cultivation, and participation in farmer groups enhance the rapid spread of technologies (Foltz, 2003; Marenya and Barrett, 2007). Farmers usually face challenges in processing information about the technologies and often suffer fatigue when involved in experimentation (Gwaze et al., 2011; AGRA, 2016). Given the long gestation period of some ISFM packages such as agroforestry, best fits that offer lower investment risk and uncertainty in outputs in the long term are expected to be adopted easily (Foltz, 2003; Odendo et al., 2010).

\section{Results}

The Chi-squared test shows that the penta-variate probit model (Table 1) had a good fit with Likelihood ratio test of $\mathrm{rho}_{21}=, \quad \ldots,=\operatorname{rho}_{54}=0 ; \quad \operatorname{chi}^{2}(10)=111.994 \quad$ Prob $>$ $\mathrm{chi}^{2}=0.0000$. The high significance of off-diagonal values of the error covariance matrix $\left(/ \mathrm{artho}_{\mathrm{ij}}\right)$ and correlation matrix $\left(\mathrm{rho}_{\mathrm{ij}}\right.$ ) shows that seven out of 10 possible outcomes for ISFM component combinations were simultaneously modelled. However, we see that there is weak evidence to prove interdependence within some combinations where the error covariance matrix (/atrho 41 , $/$ atrho $_{51}$, and /atrho 32 ) and error correlations $\left(\mathrm{rho}_{41}\right.$ and $\left.\mathrm{rho}_{51}\right)$ are subtly nonsignificant (Table 1). This implies that there are heterogeneous factors that influence the adoption decisions of multiple ISFM components.

The study reveals differentiated usage patterns for the soil fertility management technologies in the Chinyanja Triangle with respect to farm, farmer, and interrelated attributes (Table 1 and Figure 2). It has been observed that farmers choose from a set of five commonly used soil fertility management options depending on their socioeconomic conditions as well as the land size and perceived 
Table 1. Penta-variate probit results for multiple and interdependent decisions of ISFM technologies

\begin{tabular}{|c|c|c|c|c|c|}
\hline Variables & $\begin{array}{c}\text { 1. Inorganic fertilizer } \\
\text { Coef. }\end{array}$ & $\begin{array}{l}\text { 2. Farmyard manure } \\
\text { Coef. }\end{array}$ & $\begin{array}{l}\text { 3. Residue incorporation } \\
\text { Coef. }\end{array}$ & $\begin{array}{l}\text { 4. Grain legumes } \\
\text { Coef. }\end{array}$ & $\begin{array}{l}\text { 5. Crop rotation } \\
\text { Coef. }\end{array}$ \\
\hline Landsize/person & $-0.09^{*}$ & $-0.15^{*}$ & $-0.18 * * *$ & -0.03 & $0.14 * * *$ \\
\hline No. of plots & & $0.09^{*}$ & & $-0.20 * * *$ & $-0.17 * * *$ \\
\hline Moderate fertility & -0.05 & 0.07 & & & $0.19 *$ \\
\hline Education (head) & 0.02 & $0.01 * *$ & 0.01 & $0.05^{* *}$ & $0.07 * * *$ \\
\hline Sex (head) & $0.41 *$ & 0.04 & & 0.20 & 0.05 \\
\hline Labour & -0.07 & $0.00^{* *}$ & 0.03 & 0.05 & 0.05 \\
\hline Age (head) & $0.02 * * *$ & $0.01 * * *$ & $0.01 *$ & 0.00 & 0.00 \\
\hline Sell at farm-gate & & & & 0.04 & $-0.41 * *$ \\
\hline Sell in a group & 0.53 & & & -0.25 & 0.15 \\
\hline Cellphone & $0.59 * * *$ & 0.38 & & 0.04 & \\
\hline Livestock units & 0.22 & 1.15 & -0.17 & 0.29 & -0.08 \\
\hline Non-farm income & $3.03 * * *$ & 0.60 & $2.13 * * *$ & & $1.03^{*}$ \\
\hline Credit constraint & -0.10 & & & & $0.26^{*}$ \\
\hline Climate change & 0.28 & 0.60 & $0.45^{*}$ & 0.44 & 0.19 \\
\hline Livestock loss & $0.62 * *$ & 0.61 & $-0.43 *$ & $-0.46^{*}$ & $-0.52 * *$ \\
\hline Crop loss & -0.49 & -0.25 & $-0.63 *$ & 0.12 & -0.19 \\
\hline Extension contact & 0.04 & 0.10 & -0.08 & -0.06 & -0.01 \\
\hline _Constant & -0.75 & -1.34 & $-1.09 * *$ & -0.51 & $-1.15^{* *}$ \\
\hline
\end{tabular}

\begin{tabular}{|c|c|c|c|c|c|c|c|}
\hline & Coef. & & Coef. & & Coef. & & Coef. \\
\hline atrho $_{21}$ & $0.39 * * *$ & atrho $_{42}$ & $0.31^{* * *}$ & $\mathrm{rho}_{21}$ & $0.37 * * *$ & $\mathrm{rho}_{42}$ & $0.30^{* * *}$ \\
\hline atrho $_{31}$ & $0.42 * * *$ & atrho $_{52}$ & $0.30^{* * *}$ & $\mathrm{rho}_{31}$ & $0.40 * * *$ & rho $_{52}$ & $0.29^{* * *}$ \\
\hline atrho $_{41}$ & 0.13 & atrho $_{43}$ & $0.38^{* * *}$ & $\mathrm{rho}_{41}$ & 0.13 & $\mathrm{rho}_{43}$ & $0.36^{* * *}$ \\
\hline atrho $_{51}$ & 0.19 & $\operatorname{atrho}_{53}$ & $0.58 * * *$ & $\mathrm{rho}_{51}$ & 0.19 & rho $_{53}$ & $0.52 * * *$ \\
\hline atrho $_{32}$ & 0.17 & $\operatorname{atrho}_{54}$ & $1.08 * * *$ & $\mathrm{rho}_{32}$ & $0.17 *$ & rho $_{54}$ & $0.79 * * *$ \\
\hline
\end{tabular}

Notes: ${ }^{* * *}$, and $* * *$ denote significance at 10,5 and $1 \%$ level of statistical error, respectively. artho $_{\mathrm{ij}}=$ error covariance; rho $_{\mathrm{ij}}=$ error correlations; blank $^{*}$ cells indicate that the variables were excluded from the model

soil fertility. Apparently, nonfarm income has a larger significant effect on adoption of multiple ISFM components. The direction and magnitude of effects are discussed in the following paragraphs. The results are grouped into household resource endowments, plot and farm characteristics, socio-demographic factors, markets and access to financial resources, and biophysical limits experienced by the studied households.

\subsection{Household resource endowments}

The results show that a unit increase in land size in hectares per capita reduces the propensity that farmers will apply inorganic fertiliser, farmyard manure, and residue incorporation. It is also interesting to note that households with larger land per capita apparently rotate crops while those with small sizes have a higher probability to continuously grow the same crops on their fields. When considering labour availability (total family labour in man equivalents), the study has found that there is a higher tendency for farmers to apply farmyard manure with increasing family labour.

\subsection{Plot and farm characteristics}

Land fragmentation in terms of number of plots owned has been found to increase the likelihood that households adopt farmyard manure, but significantly reduces the probability of growing grain legumes and practising crop rotation. Our result shows that land fragmentation negatively influences both legume cropping and crop rotation. Overall, the results show the reason behind farmers' choice of residue incorporation, grain legumes, and crop rotation is largely enhanced by their perceptions of land being less fertile. In other words, farmers who consider that their fields are below average in terms of fertility - that is, require 

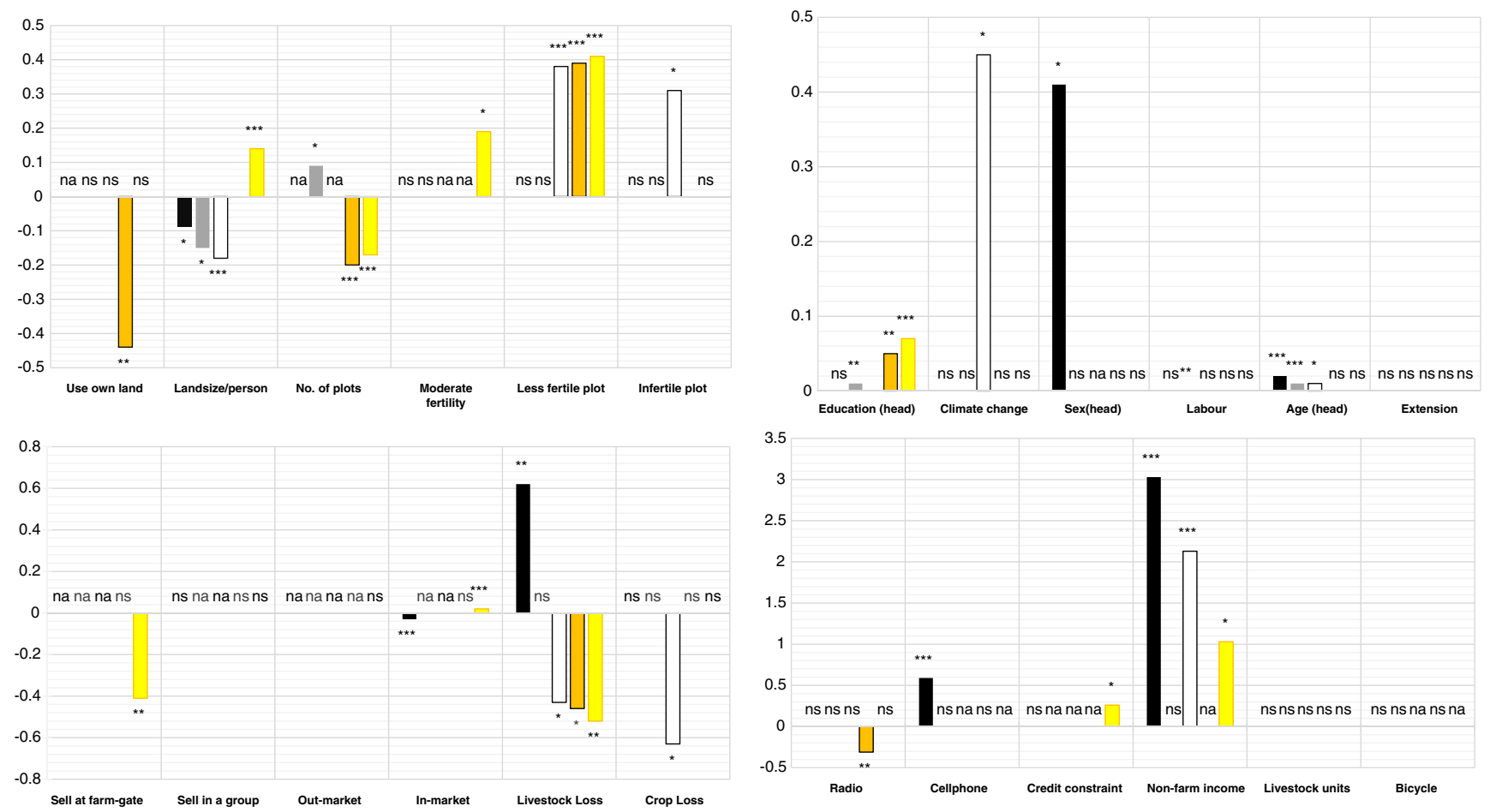

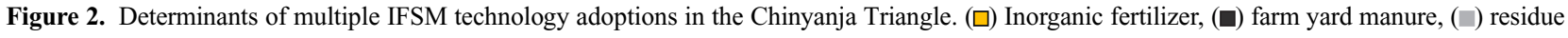
incorporation, ( $\square$ ) grain legumes and ( $)$ crop rotation.

considerable inputs to be productive - have a higher likelihood of using residue incorporation, grain legumes, and crop rotation. We see that farmers who perceive their fields to be moderately fertile have a higher propensity (probability 0.19 ) to rotate crops compared to those with fertile lands. Lastly, the study has established that farmers are more likely to incorporate residues on infertile plots than on fertile plots.

\subsection{Household demographic factors}

Education levels are quite low in the region, with few farmers attaining post primary education. The majority drop out of primary school. The probability of applying farmyard manure, grain legumes, and crop rotation in improving soil fertility increases by $0.01,0.05$ and 0.07 for every unit increase in the number of years of formal education attained by the main decision maker - the household head. In terms of socio-demographic attributes, the results show that male-headed households have a higher probability of applying inorganic fertiliser than their female-headed counterparts. In this study, households headed by young persons have a lower propensity of applying fertiliser and farmyard manure, as well as incorporating residues.

In addition to differentiation by demographic and physical assets, the study also points out that access to input markets significantly categorises farmers in terms of their current practices regarding inorganic fertiliser and crop rotation. Households located $1 \mathrm{~km}$ further from the input market had a lower chance of accessing inorganic fertiliser, but were more likely to rotate crops. The place of sale of farm produce also influences the practice of crop rotation. The study found that selling at the farm's gate reduces the propensity to rotate crops compared to selling at the output markets located at trading centres or mobile markets.

Like input and output market access, increased access to information had positive effect on the usage of inorganic fertiliser in the region. Farmers who owned mobile phones could share information with extension officers and service providers, and thus had a greater propensity of applying fertiliser. On the contrary, farmers with access to information through radio have a lower propensity of growing legumes on their fields. There is also a high likelihood that farmers with nonfarm income are also more likely to practise residue incorporation and crop rotation. To assess the impact of financial constraints on ISFM adoption, the variable "financial constraint" was used as the condition when farmers need finances but do not have opportunity to access. Farmers who are not constrained financially and either do not need credit or are able to access credit tend to rotate crops.

\subsection{Environmental shocks experienced by the household}

Of the five practices under consideration, the study shows that farmers who are aware of climate variability and its effects are more likely to practise residue incorporation. Livelihood shocks, such as loss of a great proportion of livestock, are positively related to the use of inorganic 
fertiliser while they derail farmers' willingness to practice residue incorporation, grain legume cropping, or crop rotation. The results show that if farmers lose at least $50 \%$ of their crops, the probability of them incorporating crop residues is significantly reduced. As much as farmers who are aware of climate shocks used residue incorporation, farmers who lost crops due to drought, mismanagement, or theft are not likely to incorporate residues.

\section{Discussion}

Considering farming as the main livelihood strategy for small-scale farmers, the importance of managing soils cannot be understated, and is mainstreamed into several other programmes. The complexity of approaches that have multiple technologies, methods, and benefits, such as ISFM, poses analytical problems. This study has revealed that existing resource endowments - such as labour, land size, social services, and institutions - including education, land reforms, and natural hazards, may present trade-offs and synergies on usage of ISFM packages by smallholder farmers in the Chinyanja Triangle.

\subsection{ISFM adoption and land size, family labour, and land fragmentation}

It has been well established that most farmers in the study region mainly use family labour, which can be constrained with increasing land size (Amede et al., 2014). In this study, it has been found that the larger the household size, the higher the tendency to maximise space utilisation by investing in soil management interventions such as inorganic fertilizer, farmyard manure, and residue incorporation. The application of fertiliser requires financial input whilst at the moment, farmyard manure and residue incorporation rely on local availability and labour. Theoretically, it is expected that larger land holdings are associated with an increased availability of financial resources, which in turn could enable the former (Akinola et al., 2010). Moreover, as the theory of economies of scale implies, small land per capita implies that returns to investment on units of land are small, rendering it to be not worth investing in (Morris et al., 2007). Farmers with small land sizes per person experience higher pressure to feed individual members; hence, they could be investing in these high input technologies to maintain or improve productivity that declines due to continuous cultivation (Mponela et al., 2016). These households are faced with a greater challenge to get the most out of the land to generate enough for food and non-food returns, and thus may test and use several technologies at their disposal.

Coincidentally, those with more family labour tend to use farmyard manure. The study in western Kenya found that manure usage is concentrated around homesteads (Vanlauwe et al., 2006). In the Chinyanja Triangle, the most common method of transportation is a 'person's head'; thus, the carrying of bulky manure to fields may pose a limitation that the available labour addresses (Amede et al., 2014). With the nuclear settlement systems, a few individuals own land parcels closer to the village settlement; hence, only those with larger family sizes manage to transport enough farmyard manure. On the contrary, the study has found that, given farm size per capita as a limitation, farmers in the Chinyanja Triangle are more likely to use crop rotation in isolation. This only shows that landrich families rely on biological nutrient replenishment and other agronomic benefits that crop rotation offers. This result is expected, as more land size implies that farmers can allocate different portions to different crops.

Land fragmentation implies that each household owns several portions of smaller farms in different locations. Since landholding in the study area is already small, fragmented plots tend to be much smaller (Jayne et al., 2003). Several previous studies of adoption used total land owned, which may obscure the effects of fragmentation. Land fragmentation promotes equitable redistribution of land, which local bylaws may inherently promote. As Kebede (2006) and Gebreselassie (2006) indicated in their reports from Ethiopia, land fragmentation is considered to be a positive phenomenon in smallholder systems since some of the plots could be located in fertile soil zones. Again, based on empirical findings by Tittonell et al. (2005) from studies in Western Kenya, plots closer to homesteads tend to be more fertile since they receive higher levels of attention and nutrient inputs. In the case of the Chinyanja Triangle, with nuclear settlements, there is a potential soil fertility gradient from the village settlements to plots located further away. These obviously have implications on the ISFM choices observed in this paper, as discussed below.

In the study area, farmers own fewer small ruminants and poultry (Amede et al., 2014), which generally produce smaller but high quality (nutrient dense) manure. For farmers who own some small fragmented plots, such small amounts of manure might improve crop yield to offset investment in transport, and thus are incentivised to apply manure. As purported by Tittonell et al. (2005) and Pears (2012), manure is generally used on fields closer to homesteads than those that are distant. Though manure application depends on mode of transport (Pears, 2012), fewer people in the study area own ox-carts; hence, for the majority of farmers, transporting bulky manure to distant plots on their heads is prohibitive (Tittonell et al., 2005; Amede et al., 2014).

It is generally expected that farmers with several fragmented plots are more likely to diversify and rotate crops than those with a single plot (Bentley, 1987). This holds especially true in areas where land allocation to crops and rotations are enforced by law (Sundqvist and Andersson, 2006). In the study region, crop choice and rotation options are based on sole decisions of individual farmers (Dalupan et al., 2015; Sambo et al., 2015). Depending on the soil 
fertility status and ease of management, farmers assign the most productive plots to high value crops and eventually face challenges in dealing with crops that require frequent rotation, such as hybrid maize varieties (Chirwa, 2008). Apparently, farmers who do not rotate crops would not be considering the residual nitrogen build-up and phosphorus availability improvement benefits that legumes offer to non-legumes in rotation. Even if they grow legumes, without rotation, they may not benefit, and the legume would not be considered as a biological ISFM component.

\subsection{Farmers' perceptions of soil fertility as a basis for ISFM adoption}

Farmers' perceptions of soil fertility of the plots they own is one the key considerations they make as to whether to embark on soil fertility management. In the past, land was abundant and farmers practised shifting cultivation whereby they could open new areas and cultivate for a few years, abandon them afterwards, and then clear adjacent fertile areas. Towards the end of the nineteenth century, shifting cultivation was being replaced by bushfallows since arable natural areas became relatively scarce, and people started to settle in one location (Boserup, 1965). They could leave these lands to regain fertility through natural fallow and later unwillingly adopted means to support annual cultivating, which includes manuring. The main aim of shifting cultivation, fallowing, and manuring is to maintain the perceived fertility levels at certain levels. With the most fertile land (proxy of virgin fertile land) as a base case, farmers with less fertile fields strive to ensure that their fields do not degrade further, and indulge in practices that aim at maintaining or reclaiming productivity. Infertile soils are generally usually non-responsive to inorganic fertilizer inputs, and the biomass-based practices are considered the most suited options to rejuvenate those (Vanlauwe et al., 2010). In principle, the biomass produced from infertile plots is too little to build the nutrient up to the minimum required levels; hence, substantial complementary fertilizer is used to get better yields. This study confirms previous findings that landowner's perceptions of soil fertility drive their intentions and influence their decisions to use a particular technology/practice (Adesina, 1995; Cary and Wilkinson, 1997; Mponela et al., 2016). Odendo et al. (2010) purports that soil fertility degradation is a slow process, yet farmers' perceptions of the severity of the problem and associated yield losses are critical in influencing adoption of soil fertility enhancing practices.

\subsection{Age and ownership of livestock as drivers of multiple ISFM adoption}

The acquisition and sharing of resources within communities has been found to have a strong bearing on future prospects from the farming enterprises. Generally, people with knowledge of the systems, either through accumulation of knowledge with age or knowledge acquisition through formal education, tend to have a higher probability of adopting farming technologies. In this study, we thus tested for interaction and quadratic relationships with regard to years of education and age, but their inclusion did not change the results. In similar studies within the region, Morris et al. (2007) and Amede et al. (2014) found that older men have higher chances of owning and acquiring resources.

Livestock are generally owned by older parents, while the youth often acquire them through inheritance. For the older farmers, this creates the opportunity to incorporate manure in their farms. Because manure is not mostly traded, those who do not own livestock (in this case the youth) will not have the input to apply to their farms. With the social resource transfer programmes (where households are given livestock - mainly, a cow, a goat, or a pig, and pass on the offspring(s) to neighbours), which is promoted by the government, nongovernmental organisations (NGOs), and the private sector's contract farming - which is common in the region - it is again the older men who have strong social ties and access more input opportunities. Regionally, it is reported that farming is more and more becoming a profession for the elderly, while the youth shun it for other professions (IFAD, 2016).

Despite having plots of land to manage, the youth generally consider agriculture as a less attractive and risky business, and thus tend to look for other options. Consequently, young farmers spend more time on off-farm activities and even when they have manure, they do not have much time to collect and apply the manure, which is a more labour-intensive option. On the flip-side, manure application is labour-intensive and difficult for the elderly, and could be easier for the youth. In addition, the youthful family heads likely exert limited effort to avail labour to incorporate residue on farm plots.

\subsection{Information and financial constraints}

Access to information and financial resources are also considered to be factors that influence the adoption of technologies by smallholder farmers. These two factors are controlled by external agents and are often skewed and inaccessible, especially to villagers. As observed in previous studies of information channels, there has been much focus on crop-specific programmes, and very little on soil management, being aired on the radio for commercial purposes (Manda, 2011; Ndilowe, 2013). In Malawi, the government generally promotes maize and other crops, such as groundnuts, for export, influencing farmers to be attracted to "valuable" crops. Another study in Malawi showed that although the majority of the agricultural radio programmes highlight issues of food security and farming systems, about $60 \%$ of the broadcasts are funded by various 
institutions and companies marketing their specific information (Mloza-Banda, 2011). The emphasis on marketoriented messaging for specific crops or value chain approaches for radio programming (Manda, 2011) undermines its role in disseminating information about the use of legumes for soil fertility in the farming system.

In addition, radio has a role in promoting maize as a staple food, which is being promoted by the governments to address persistent hunger. A generally subsistence orientation also puts the staple crop - maize - at a higher ranking such that every farmer with small land size strives to continuously grow it, including in unproductive soils or when weather projections are not favourable. Moreover, farmers are not sure if they can buy maize by selling other crops because the price of crops is generally low and volatile (Minot, 2014; Sassi, 2015).

Farmers who are not financially constrained have a greater potential to diversify technology usage on farms. Financial sources to support farming apparently dictate the kind of investment to be made in the farm. As noted by Chalmers and Agar (2015), farmers in the region have multiple livelihood portfolios. They shift resources from one investment portfolio to another depending on the season. Chalmers and Agar noted that multiple investments enable farmers "to move resources to address cash flow shortages and seasonality in each business, manage uncontrollable downside risks by moving resources from businesses affected by such a risk, and manage growth opportunities by investing in businesses that are making most progress". Farming is considered to be the main livelihood strategy; hence, farmers with income from other sources (including permanent employment, business enterprises, and temporary labour) have a higher propensity to re-invest by purchasing inorganic fertiliser. This finding shows that financial sources empower farmers to be able to move out of the single crop trap, which has ecological consequences in the long run. Crop rotation is one of the agronomically sound practices in dealing with pests and diseases, as well as sustaining soils. Farmers with finances have several choices and investment opportunities to make.

\subsection{Climate change as a trigger for ISFM technology use}

In the Chinyanja Triangle and surrounding regions, organic soil fertility sources are considered to be main climate change adaptation strategies. These organic sources captured in this study, including farmyard manure and crop residues, contribute to an improvement in organic soil matter and soil health, thereby improving rooting, water holding capacity, and nutrient retention. This study shows that farmers who experienced climate change effects, including drought and flooding, were more likely to incorporate crop residues. From the findings, it is not clear if these farmers would use inorganic fertilisers.

\section{Conclusion}

These results are of importance to researchers, practitioners, and decision makers who design strategies aimed at promoting these ISFM technologies as a package. The paper has revealed quite divergent empirical reasons for the preferences of farmers to practise ISFM components. This shows that farmers are faced with multiple constraints ranging from resource scarcity, financial constraints, and higher learning costs to variability in production, which increases risk aversion. Here are a few conclusions that can be drawn from the results.

Adoption of more than one ISFM technology by land resource-constrained farmers could also be an indication of the complementary effects that these technologies share in addressing low soil fertility and improving productivity of small-scale farms. Population pressure and climatic uncertainties (variability and extreme events) have forced communities in the majority of smallholder farms in the Chinyanja Triangle to resort to unsustainable and inefficient resource use, including the exploitation of fragile areas. Households at different places on the spectrum of livelihood conditions will consider different criteria when planning land and technology use. Potential production risk associated with inherent land quality, variability in climatic patterns, and farmers' apparent risk aversion tendencies do also have a significant impact on technology adoption. Depending on circumstances, farmers can decide to adopt single or multiple technologies to enhance their farm productivity. Given the heterogeneity of farm households in terms of their characteristics and their way of making decisions, there are many lessons to be learned from assessing the adoption of the different components of composite technology - such as ISFM.

Given the current farming conditions, policies, and programmes that aim at increasing land size per capita would not promote the combination of inorganic fertilisers, farmyard manures, and crop residues as limited sizes per capita have been found to favour simultaneous usage. On the other hand, increasing land to person ratio would promote crop rotation. Land fragmentation, despite having a positive influence on the likelihood of using farmyard manure, restricts farmers from using legumes as a soil fertility improvement component in rotation cropping systems. The ongoing research on legume integration for nitrogen fixation in cereal-dominated farming systems needs to target farmers with consolidated plots. The combination of residue incorporation, grain legumes, and crop rotation is practised by farmers whose land is still moderately fertile. Promotional messages for these technologies should focus not only on degraded farms, but would have a high impact if they are promoted for moderately fertile plots. For infertile plots, promotion of residue incorporation would be the most viable option given current farmer preferences and corresponding controlling factors. 
Among the sociodemographic factors, education of the household head has been found to positively influence the coadoption of farmyard manure, grain legumes, and crop rotation. Promoting gender-based interventions would promote usage of inorganic fertilisers by women-headed households. Input/output market access, access to information, financial sources, and climate variability also play pivotal roles in technology adoption. Having other sources of income supports the co-adoption of inorganic fertiliser, residue incorporation, and crop rotation. In general, these results showed that farmers choose from a set of commonly used soil fertility management options depending on their socioeconomic conditions as well as land size and perceived soil fertility.

Those who attained a higher level of education have the capacity to acquire and process the knowledge and understand the benefits accrued. Although the education levels are low in the region, the study shows that farmers with more years of formal education could be used as agents of change when promoting these technologies.

\section{Acknowledgements}

We thank all the farmers who took their time to share with us their farming experiences in the three study countries. We also thank the enumerators and extension agents in the three study countries.

\section{References}

Adesina, A., 1995. Farmers' perceptions and adoption of new agricultural technology: Evidence from analysis in Burkina Faso and Guinea, West Africa. Agricultural Economics, 13(1): 1-9.

AGRA, 2016. Going Beyond Demos to Transform African Agriculture: The Journey of AGRA's Soil Health Program. Alliance for a Green Revolution in Africa, Nairobi.

Ajayi, O.C., Akinnifesi, F.K., Sileshi, G., Chakeredza, S., 2007. Adoption of renewable soil fertility replenishment technologies in the southern African region: Lessons learnt and the way forward. Natural Resources Forum, 31(4): 306-317.

Akinola, A.A., Alene, A.D., Adeyemo, R., Sanogo, D., Olanrewaju, A.S., Nwoke, C., Nziguheba, G., 2010. Determinants of adoption and intensity of use of balance nutrient management systems technologies in the northern Guinea savanna of Nigeria. Quarterly Journal of International Agriculture, 49(1): 25-45. Available at https://www.agrar.huberlin.de/de/institut/departments/daoe/publ/qjia/ contents/2010/1-10/Akinola (accessed 10 May 2014).

Amede, T., Tamene, D.L., Harris, D., Kizito, F., Xueliang, C. 2014. The Chinyanja Triangle in the Zambezi River Basin, southern Africa: Status of, and prospects for, agriculture, natural resources management and rural development. International Water Management Institute (IWMI). Available at http://www.iwmi.cgiar.org/Publications/wle/r4d/wle_research_for_ development-learning_series-1.pdf (accessed 1 December 2016).

Bationo, A., Waswa, B., Kihara, J., Kimetu, J. (Eds.), 2007. Advances in Integrated Soil Fertility Management in Sub-Saharan Africa: Challenges and Opportunities. Springer, Berlin.

Belderbos, R., Carree, M., Diederen, B., Lokshin, B., Veugelers, R., 2004. Heterogeneity in R\&D cooperation strategies. International Journal of Industrial Organization, 22(8-9): 1237-1263.
Benson, T., 1997. Area Specific Fertiliser Recommendations for Hybrid Maize Grown by Malawi Smallholder. Chitedze Agricultural Research Station, Lilongwe.

Bentley, J.W., 1987. Economic and ecological approaches to land fragmentation: In defense of a much-maligned phenomenon. Annual Review of Anthropology, 16(1): 31-67.

Bezu, S., Kassie, G.T., Shiferaw, B., Ricker-Gilbert, J., 2014. Impact of improved maize adoption on welfare of farm households in Malawi: A panel data analysis. World Development, 59: 120-131.

Boserup, E., 1965. The Conditions of Agricultural Growth: The Economics of Agrarian Change under Population Pressure. George Allen \& Unwin, London.

Cappellari, L., Jenkins, S.P., 2003. Multivariate probit regression using simulated maximum likelihood. The Stata Journal, 3(3): 278-294.

Cary, J.W., Wilkinson, R.L., 1997. Perceived profitability and farmers‘ conservation behaviour. Journal of Agricultural Economics, 48(1-3): 13-21.

CGIAR. 2014. Chiefs in Chinyanja Triangle. Available at www.youtube. com/watch?v=TX 1b1a_64dM (accessed 24 November 2014).

Chalmers, G., Agar, J. 2015. Portfolio ownership among agribusiness SMES in Malawi. USAID. January 13, 2015. Available at https:// www.microlinks.org/sites/default/files/resource/files/Malawi_SME_ Assessement_Brief_1.13.15_508_Compliant.pdf (accessed 12 June 2016).

Chilimba, A.D.K., Shano, B., Chigowo, M.T., Komwa, M.K., 2005. Quality Assessment of Compost Manure Produced by Smallholder Farmers in Malawi. Department of Agricultural Research Services, Republic of Malawi, Lilongwe. Available at http://www.ndr.mw:8080/xmlui/ handle/123456789/350 (accessed 2 February 2013.

Chilonda, P., Otte, J., 2006. Indicators to monitor trends in livestock production at national, regional and international levels. Livestock Research for Rural Development, 18(8): 117. Available at http://www.lrrd.cipav. org.co/lrrd18/8/chil18117.htm (accessed 22 May 2017).

Chirwa, E.W. 2008. Land tenure, farm investments and food production in Malawi. Discussion Paper No. 18. University of Manchester, Manchester. Available at http://www.eldis.org/vfile/upload/1/document/1106/ Land $\% 20$ tenure $\% 20$ farm $\% 20$ investments $\% 20$ and $\% 20$ food $\% 20$ production \%20in\%20Malawi\%5B1\%5D.pdf (Accessed 07 October 2017).

Coe, R., Njoloma, J., Sinclair, F., 2016. Loading the dice in favour of the farmer: Reducing the risk of adopting agronomic innovations. Experimental Agriculture: 1-17. https://doi.org/10.1017/S0014479716000181.

Dalupan, M.C.G., Haywood, C., Wardell, D.A., Cordonnier-Segger, M.C., Kibugi, R., 2015. Building Enabling Legal Frameworks for Sustainable Land-use Investments in Zambia, Tanzania and Mozambique: A Synthesis. Center for International Forestry Research (CIFOR), Bogor, Indonesia. https://doi.org/10.17528/cifor/005753.

Denning, G., Kabambe, P., Sanchez, P., Malik, A., Flor, R., Harawa, R., Nkhoma, P., Zamba, C., Banda, C., Magombo, C., Keating, M., Wangila, J., Sachs, J., 2009. Input subsidies to improve smallholder maize productivity in Malawi: Toward an African green revolution. PLoS Biology, 7(1): e1000023. https://doi.org/10.1371/journal.pbio.1000023.

Dixon, J., Gulliver, A., Gibbon, D., 2001. Farming Systems and Poverty: Improving Farmers' Livelihoods in a Changing World. FAO \& World Bank, Rome and Washington, DC. Available at http://www.fao.org/3/ a-ac349e.pdf (accessed 6 February 2014).

Doss, C.R., 2006. Analyzing technology adoption using microstudies: Limitations, challenges, and opportunities for improvement. Agricultural Economics, 34(3): 207-219.

Feder, G., 1985. The relation between farm size and farm productivity: The role of family labor, supervision and credit constraints. Journal of Development Economics, 18(2-3): 297-313.

Foltz, J.D., 2003. The economics of water-conserving technology adoption in Tunisia: An empirical estimation of farmer technology choice. Economic Development and Cultural Change, 51(2): 359-373.

Foster, A.D., Rosenzweig, M.R. 2010. Microeconomics of technology adoption. Center Discussion Report No. 984. Yale University, New Haven, CT. 
Gebreselassie, S. 2006. Land, land policy and smallholder agriculture in Ethiopia: Options and scenarios. Discussion Paper No. 008 Future Agricultures. p. 14. Available at http://www.future-agricultures.org/ publications/research-and-analysis/discussion-papers/25-land-land-policy -and-smallholder-agriculture-in-ethiopia/file (accessed 22 May 2017).

Giller, K.E., Tittonell, P., Rufino, M.C., van Wijk, M.T., Zingore, S., Mapfumo, P., Adjei-Nsiah, S., Herrero, M., Chikowo, R., Corbeels, M., Rowe, E.C., Baijukya, F., Mwijage, A., Smith, J., Yeboah, E., van der Burg, W.J., Sanogo, O.M., Misiko, M., de Ridder, N., Karanja, S., Kaizzi, C., K'ungu, J., Mwale, M., Nwaga, D., Pacini, C., Vanlauwe, B., 2011. Communicating complexity: Integrated assessment of trade-offs concerning soil fertility management within African farming systems to support innovation and development. Agricultural Systems, 104(2): 191-203.

Guastella, G., Moro, D., Sckokai, P., Veneziani, M. 2013. Investment behaviour of EU arable crop farms in selected EU countries and the impact of policy reforms. Working Paper No. 42. Centre for European Policy Studies (CEPS), Brussels. p. 24. Available at http://aei.pitt. edu/58562/1/Factor_Markets_42.pdf (accessed 22 May 2017).

Gwaze, F.R., Mwale, M., Chimoyo, M., 2011. Challenges encountered in conducting farmer-oriented livestock research among resource-limited farmers of Sub-Saharan Africa: A review. African Journal of Agricultural Research, 6(21): 4840-4851.

Holden, S.T. 2015. Risk preferences, shocks and technology adoption: Farmers' responses to drought risk. Centre for Land Tenure Studies Working Paper 3. Norwegian University of Life Sciences, Ås. Available at https://www.nmbu.no/sites/default/files/pdfattachments/clts_ wp_3_2015.pdf (accessed 12 February 2016).

International Fund for Agricultural Development (IFAD), 2016. Why are rural youth leaving farming? (Vol. IFAD). Presented at the 2016 Youth Agribusiness, Leadership, and Entrepreneurship Summit on Innovation (YALESI 2016), Dakar, Senegal. Available at https://ifad. org/stories/tags/senegal/17593915 (accessed 10 September 2016).

Jahnke, H.E. 1982. Livestock production systems and livestock development in tropical Africa. Keiler Wissenschaftverlag Vauk. Available at http://pdf.usaid.gov/pdf_docs/pnaan484.pdf (accessed 1 December 2016).

Jama, B., Pizarro, G., 2008. Agriculture in Africa: Strategies to improve and sustain smallholder production systems. Annals of the New York Academy of Sciences, 1136(1): 218-232.

Jayne, T.S., Yamano, T., Weber, M.T., Tschirley, D., Benfica, R., Chapoto, A., Zulu, B., 2003. Smallholder income and land distribution in Africa: Implications for poverty reduction strategies. Food Policy, 28(3): 253-275.

Jha, D., Hojjati, B. 1993. Fertilizer use on smallholder farms in eastern province, Zambia. Research Report No. 94. International Food Policy Research Institute, Washington, DC. Available at https:// ageconsearch.umn.edu/bitstream/37967/2/rr94.pdf (accessed 24 February 2017).

Kassie, M., Teklewold, H., Jaleta, M., Marenya, P., Erenstein, O., 2015. Understanding the adoption of a portfolio of sustainable intensification practices in eastern and southern Africa. Land Use Policy, 42: 400-411.

Kebede, B. 2006. Land reform, distribution of land and institutions in rural Ethiopia: Analysis of inequality with dirty data. Working Paper No. 05. Centre for the Study of African Economies, Univeristy of Oxford. Available at https://www.csae.ox.ac.uk/workingpapers/ pdfs/2006-05text.pdf (accessed 22 May 2017).

Kravchenko, A.N., Snapp, S.S., Robertson, G.P., 2017. Field-scale experiments reveal persistent yield gaps in low-input and organic cropping systems. Proceedings of the National Academy of Sciences of the United States of America, 114(5): 926-931.

Lambrecht, I., Vanlauwe, B., Maertens, M., 2016. Integrated soil fertility management: From concept to practice in Eastern DR Congo. International Journal of Agricultural Sustainability, 14(1): $100-118$.
Langyintuo, A.S., Mungoma, C., 2008. The effect of household wealth on the adoption of improved maize varieties in Zambia. Food Policy, 33(6): 550-559.

Maat, H., 2011. The history and future of agricultural experiments. NJAS - Wageningen Journal of Life Sciences, 57(3-4): 187-195.

Manda, L.Z., 2011. Importance of radio in agricultural value chains. In: Manda, L.Z. (Ed.), Addressing Information Gaps in Agricultural Value Chains: The Role of Radio Programming. Farm Radio Malawi/Department of Agricultural Extension Services, Lilongwe. pp. 25-30). Presented at the 3rd Annual Farm Radio Symposium, Malawi Institute of Management.

Marenya, P.P., Barrett, C.B., 2007. Household-level determinants of adoption of improved natural resources management practices among smallholder farmers in western Kenya. Food Policy, 32(4): 515-536.

Minot, N., 2014. Food price volatility in sub-Saharan Africa: Has it really increased? Food Policy, 45: 45-56.

Mloza-Banda, C.B., 2011. Agriculture in changing times: Fostering knowledge sharing amongst various stakeholders. In: Manda, L.Z. (Ed.), Addressing Information Gaps in Agricultural Value Chains: The Role of Radio Programming. Farm Radio Malawi/Department of Agricultural Extension Services, Lilongwe. pp. 25-30). Presented at the 3rd Annual Farm Radio Symposium, Malawi Institute of Management.

Morris, M., Kelly, V. A., Kopicki, R. J., Byerlee, D. 2007. Fertilizer use in African agriculture: Lessons learned and good practice guidelines. The World Bank. Available at http://elibrary.worldbank.org/doi/ book/10.1596/978-0-8213-6880-0 (accessed 4 December 2016).

Mponela, P., Tamene, L., Ndengu, G., Magreta, R., Kihara, J., Mango, N., 2016. Determinants of integrated soil fertility management technologies adoption by smallholder farmers in the Chinyanja Triangle of Southern Africa. Land Use Policy, 59: 38-48.

Mueller, N.D., Gerber, J.S., Johnston, M., Ray, D.K., Ramankutty, N., Foley, J.A., 2012. Closing yield gaps through nutrient and water management. Nature, 490(7419): 254-257.

Mugwe, J., Mugendi, D., Mucheru-Muna, M., Merckx, R., Chianu, J., Vanlauwe, B., 2009. Determinants of the decision to adopt integrated soil fertility management practices by smallholder farmers in the central highlands of Kenya. Experimental Agriculture, 45(1): 61-75.

Ndilowe, U.M. 2013. An investigation of the role of communication in the Malawi agriculture sector wide approach-special project (ASWAP-SP): A closer look at conservation agriculture: The case of Mitundu Extension Planning Area (EPA) in Chisamba village. Master Thesis. University of Oslo, Oslo. Available at https://www.duo.uio.no/ handle/10852/35874 (Accessed 25 July 2017).

Njuki, J.M., Mapila, M.T., Zingore, S., Delve, R., 2008. The dynamics of social capital in influencing use of soil management options in the Chinyanja Triangle of southern Africa. Ecology and Society, 13(2): 9.

Nkonya, E., Johnson, T., Kwon, H.Y., Kato, E., 2016. Economics of land degradation in sub-Saharan Africa. In: Nkonya, E., Mirzabaev, A., von Braun, J. (Eds.), Economics of Land Degradation and ImprovementA Global Assessment for Sustainable Development. Springer International Publishing, Cham. pp. 215-259.

Odendo, M., Obare, G., Salasya, B., 2010. Farmers' perceptions and knowledge of soil fertility degradation in two contrasting sites in western Kenya. Land Degradation \& Development, 21(6): 557-564.

Pattanayak, S. K., Mercer, E. D., Sills, E. O., Yang, J.-C., Cassingham, K. 2002. Taking stock of agroforestry adoption studies. Working Paper No. 02_04. Research Triangle Institute. Available at http://www.rti. org/sites/default/files/resources/rtipaper_02_04.pdf (accessed 26 December 2016).

Pears, B., 2012. The formation of anthropogenic soils across three marginal landscapes on Fair Isle and in the Netherlands and Ireland. In: Jones, R. (Ed.), Manure Matters Historical, Archaeological and Ethnographic Perspectives. Ashgate Publishing, Franham. pp. 109-128.

Republic of Malawi, 2008. 2008 Population and Housing Census: Preliminary Report. National Statistics Office, Lilongwe. 
Republic of Zambia, 2010. 2010 Census of Population and Housing. Volume 11: National Descriptive Tables. Central Statistical Office, Lusaka.

Republica de Mocambique, 2005. Perfil do Distrito de Macanga, Provincia de Tete. Ministrerio da Administracao Estatal, Maputo.

Rodgers, E.M., 2003. Diffusion of Innovations, 5th edn. The Free Press, New York.

Rosegrant, M.W., Koo, J., Cenacchi, N., Ringler, C., Robertson, R., Fisher, M., Cox, C.M., Garrett, K., Perez, N.D., Sabbagh, P., 2014. Food Security in a World of Natural Resource Scarcity: The Role of Agricultural Technologies. International Food Policy Research Institute, Washington, DC.

Sambo, P.T., Haywood, C., Wardell, D.A., Kibugi, R., CordonnierSegger, M.C., 2015. Enabling Legal Frameworks for Sustainable Land Use Investments in Zambia: Legal Assessment Report. Center for International Forestry Research (CIFOR) Bogor, Indonesia. https:// doi.org/10.17528/cifor/005777.

Sanginga, N., Woomer, P.L. (Eds.), 2009. Integrated Soil Fertility Management in Africa: Principles, Practices and Development Process. Tropical Soil Biology and Fertility Institute of the International Centre for Tropical Agriculture, Nairobi. Available at https://agrilinks.org/ sites/default/files/resource/files/integrated_soil_fertility.pdf (accessed 19 May 2017).

Sassi, M., 2015. The welfare cost of maize price volatility in Malawi. Biobased and Applied Economics, 4(1): 77-100.

Sileshi, G.W., Akinnifesi, F.K., 2017. Comments on Coe et al. (2016) "Loading the dice in favour of the farmer". Experimental Agriculture: 1-6. https://doi.org/10.1017/S0014479717000060.

Smart, T., Hanlon, J. 2014. Agricultural land is a Mozambican resource. The case for small commercial farmers (Vol. IV, pp. 1-8). Presented at the IV Conferência Internacional do IESE. Instituto de Estudos Sociais e Económicos, Maputo. Available at http://www.open.ac.uk/ technology/mozambique/sites/www.open.ac.uk.technology.mozambique/ files/files/Small_commercial_farmers_in_Moz_Smart-Hanlon.pdf (accessed 29 November 2016).

Snyder, K.A., Miththapala, S., Sommer, R., Braslow, J., 2016. The yield gap: Closing the gap by widening the approach. Experimental Agriculture, 53(03): 1-15. https://doi.org/10.1017/S0014479716000508.

Sundqvist, P., Andersson, L. 2006. A study of the impacts of land fragmentation on agricultural productivity in Northern Vietnam. Bachelor Thesis. Uppsala University, Uppsala. Available at http://www.divaportal.org/smash/get/diva2:131275/FULLTEXT01.pdf (Accessed 14 January 2016).

Tamene, L., Mponela, P., Ndengu, G., Kihara, J., 2016. Assessment of maize yield gap and major determinant factors between smallholder farmers in the Dedza district of Malawi. Nutrient Cycling in Agroecosystems, 105(3): 291-308.

Thirtle, C., Lin, L., Piesse, J. 2003. The impact of research led agricultural productivity growth on poverty reduction in Africa, Asia and Latin America (Vol. 25). Presented at the International Association of Agricultural Economists (IAAE). Document Transformation Technologies, Durban. Available at http://ecsocman.hse.ru/data/609/661/1219/118.pdf (accessed 1 April 2017).

Tilman, D., Balzer, C., Hill, J., Befort, B.L., 2011. Global food demand and the sustainable intensification of agriculture. Proceedings of the National Academy of Sciences of the United States of America, 108(50): 20260-20264.

Tittonell, P., Giller, K.E., 2013. When yield gaps are poverty traps: The paradigm of ecological intensification in African smallholder agriculture. Field Crops Research, 143(1): 76-90.

Tittonell, P., Vanlauwe, B., Leffelaar, P.A., Shepherd, K.D., Giller, K.E., 2005. Exploring diversity in soil fertility management of smallholder farms in western Kenya: II. Within-farm variability in resource allocation, nutrient flows and soil fertility status. Agriculture, Ecosystems \& Environment, 110(3-4): 166-184.

Tsegaye, W., LaRovere, R., Mwabu, G., Kassie, G.T., 2016. Adoption and farm-level impact of conservation agriculture in Central Ethiopia. Environment, Development and Sustainability, 19(6): 2517-2533. https://doi.org/10.1007/s10668-016-9869-5.

Vågen, T.-G., Winowiecki, L. A., Tamene, D. L., Tondoh, J. E. 2015. The land degradation surveillance framework (LDSF) - Field guide v4.1. World Agroforestry Centre. Available at http://landscapeportal. org/uploaded/ldsfFieldGuide_2013_v4_1.pdf (accessed 2 March 2016).

Vanlauwe, B., Bationo, A., Chianu, J., Giller, K.E., Merckx, R., Mokwunye, U., Ohiokpehai, O., Pypers, P., Tabo, R., Shepherd, K.D., Smaling, E.M.A., Woomer, P.L., Sanginga, N., 2010. Integrated soil fertility management; operational definition and consequences for implementation and dissemination. Outlook on Agriculture, 39(1): 17-24. https://doi.org/10.5367/000000010791169998.

Vanlauwe, B., Tittonell, P., Mukalama, J., 2006. Within-farm soil fertility gradients affect response of maize to fertiliser application in western Kenya. Nutrient Cycling in Agroecosystems, 76(2-3): 171-182.

Wiredu, A. N., Martey, E., Fosu, M. 2014. Describing adoption of integrated soil fertility management practices in Northern Ghana. Presented at the Conference on International Research on Food Security, Natural Resource Management and Rural Development. Tropentag, Prague. p. 4. Available athttp://www.tropentag.de/2014/abstracts/ full/608.pdf (accessed 2 February 2016). 